\title{
Notes on the vocalizations of African Thrush (Turdus pelios)
}

Peter Boesman

In the following we briefly analyze and compare voice of the different races of African Thrush (Turdus pelios). We also try to quantify the extent of any vocal differences using the criteria proposed by Tobias et al. (2010), as a support for taxonomic review.

We have made use of sound recordings available on-line from Xeno Canto (XC).

Song is a rather continuous series of notes and short phrases, often repeated several times before switching to a different one.

Some examples of song per race, illustrated with sonograms:

chiguancoides

Gambia

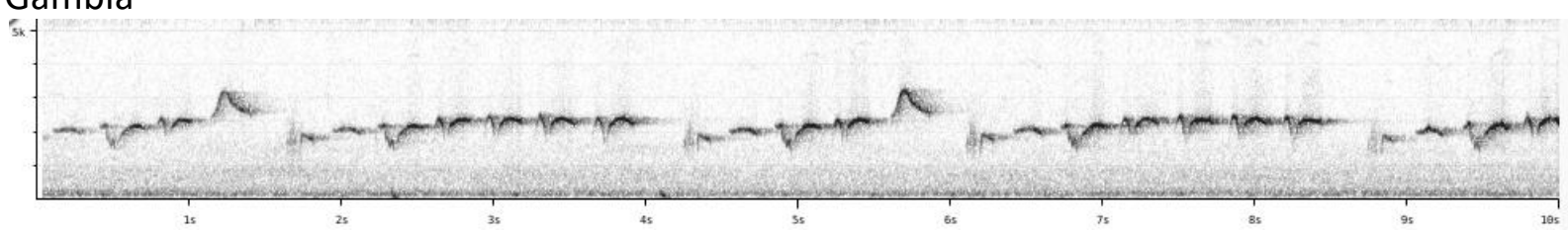

Burkina Faso

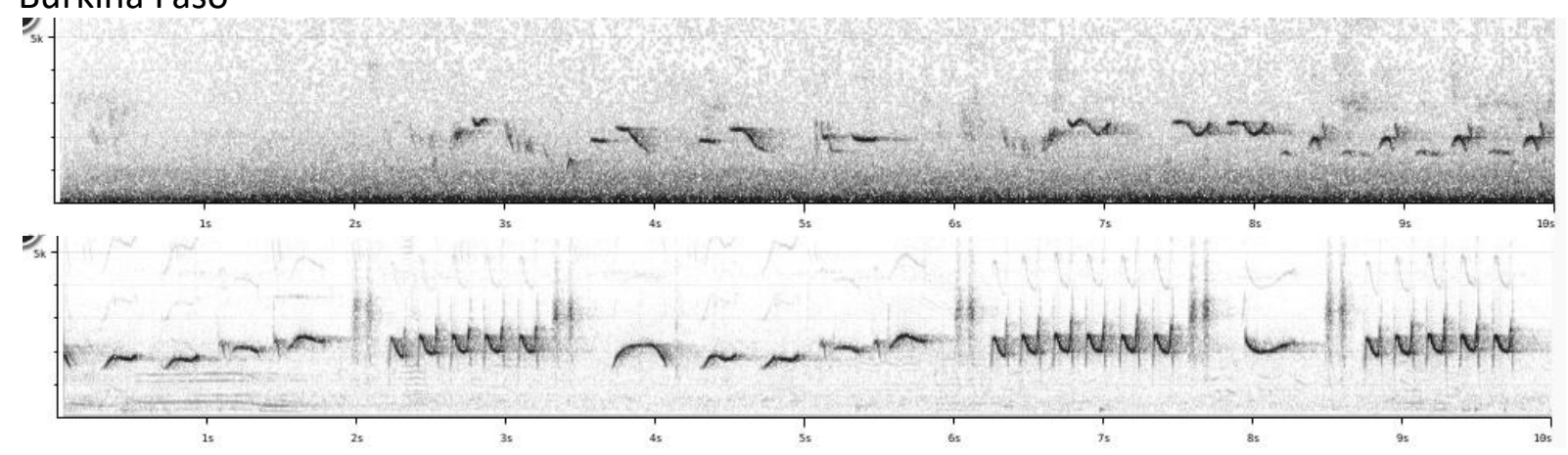

Liberia

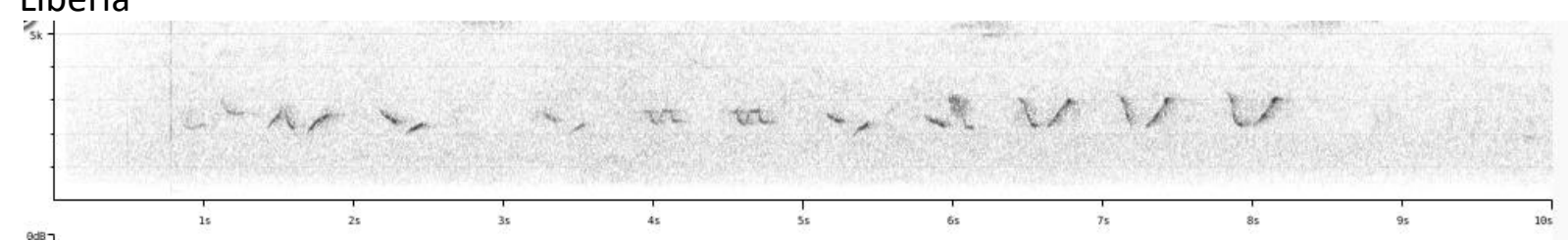

saturatus

Ghana

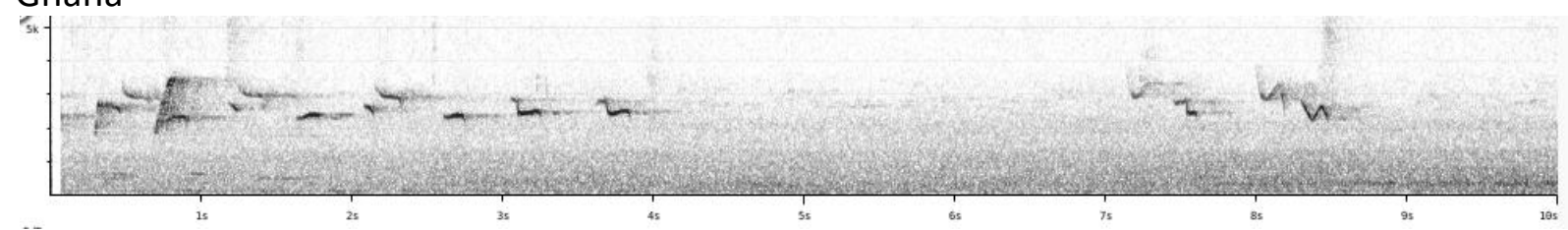




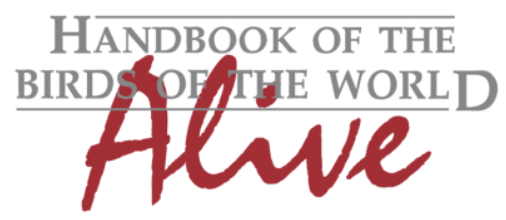

\section{ORNITHOLOGICAL NOTES}

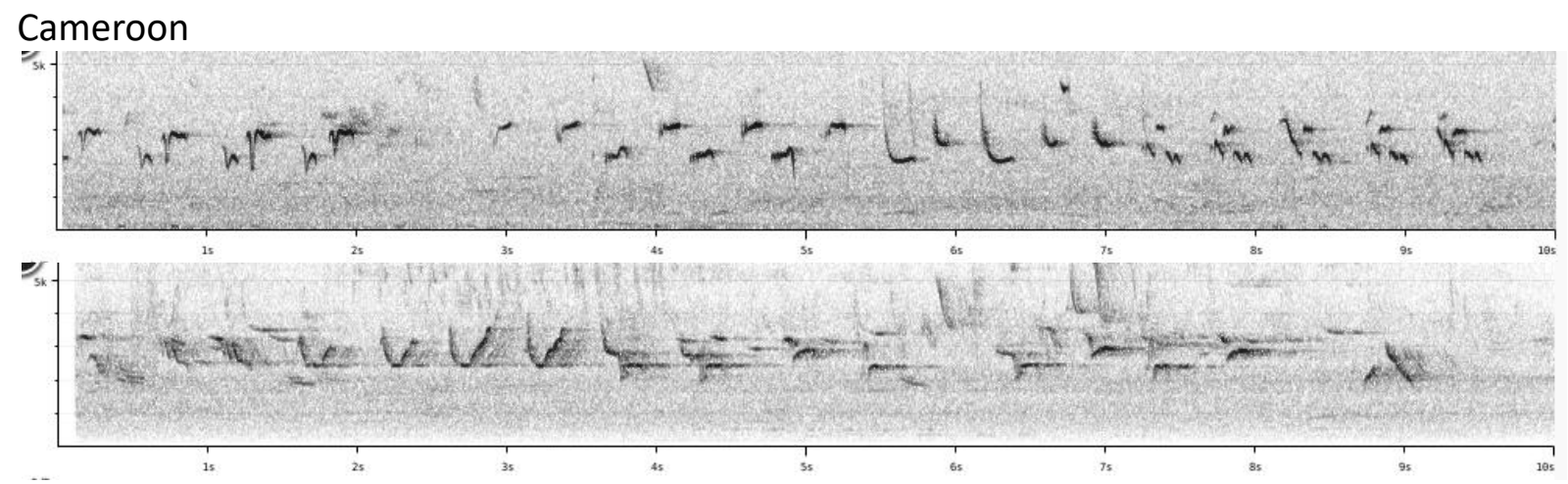

\section{$\underline{\text { centralis }}$}

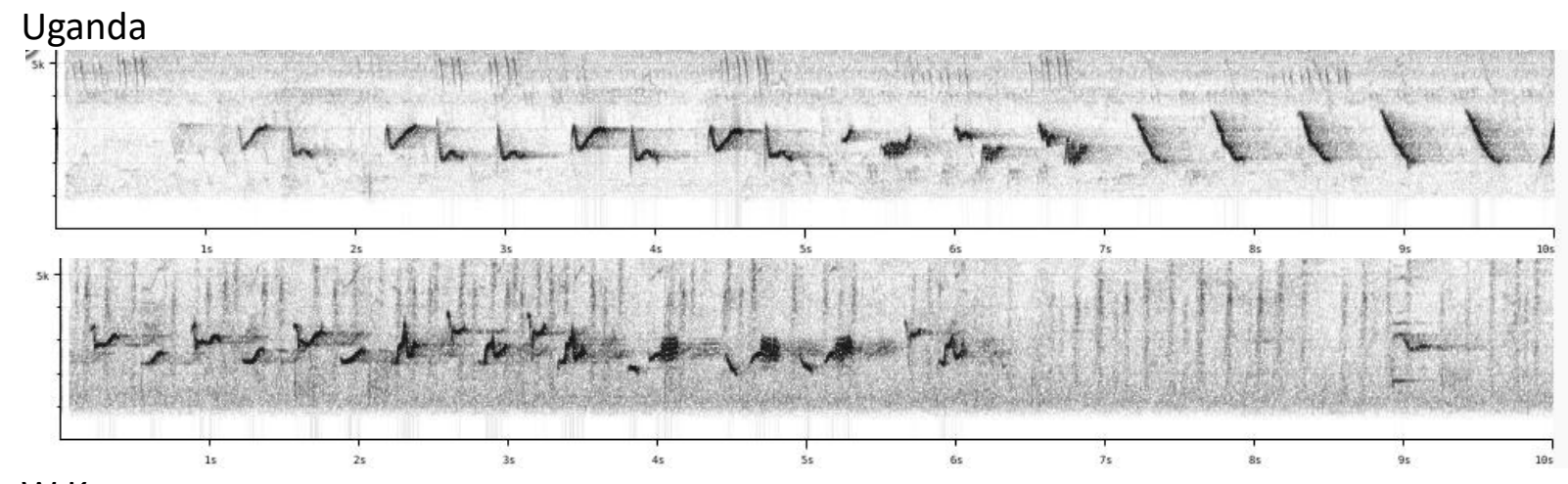

W Kenya

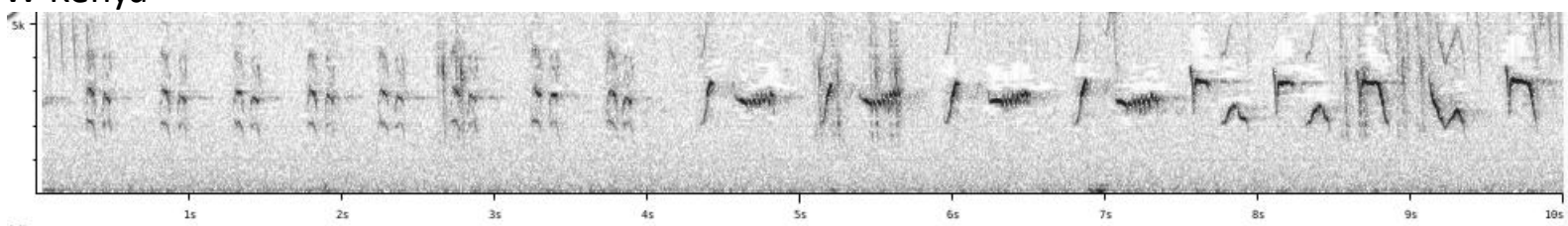

Given the variability within races (including mimicry), there are apparently no obvious differences among races. Basic sound parameters such as pace, frequency range, number of repetitions, note length and shape etc. are all rather similar.

This note was finalized on 20th April 2016, using sound recordings available on-line at that moment. We would like to thank in particular the sound recordists who placed their recordings for this species on XC: Giovanni Boano, James Bradley, Josh ENgel, Phil Gregory, Ole Jacobsen, David Moyer, Mike Nelson, Bram Piot and Martin St-Michel.

\section{References}

Tobias, J.A., Seddon, N., Spottiswoode, C.N., Pilgrim, J.D., Fishpool, L.D.C. \& Collar, N.J. (2010). Quantitative criteria for species delimitation. Ibis 152(4): 724-746. 


\section{Recommended citation}

Boesman, P. (2016). Notes on the vocalizations of African Thrush (Turdus pelios). HBW Alive Ornithological Note 311. In: Handbook of the Birds of the World Alive. Lynx Edicions, Barcelona. (retrieved from http://www.hbw.com/node/1251828 on 18 October 2016). 